\title{
One is Not Enough: The Need for Multiple Respondents in Survey Research of Organizations
}

Joseph L. Balloun

MercerUniversity, balloun_jl@mercer.edu

Hilton Barrett

Elizabeth City State University, hbarrett@mail.ecsu.edu

Art Weinstein

Nova Southeastern University, art@huizenga.nova.edu

Follow this and additional works at: http://digitalcommons.wayne.edu/jmasm

Part of the Applied Statistics Commons, Social and Behavioral Sciences Commons, and the Statistical Theory Commons

\section{Recommended Citation}

Balloun, Joseph L.; Barrett, Hilton; and Weinstein, Art (2011) "One is Not Enough: The Need for Multiple Respondents in Survey Research of Organizations," Journal of Modern Applied Statistical Methods: Vol. 10 : Iss. 1 , Article 26.

DOI: $10.22237 /$ jmasm/1304223900

Available at: http://digitalcommons.wayne.edu/jmasm/vol10/iss1/26

This Regular Article is brought to you for free and open access by the Open Access Journals at DigitalCommons@WayneState. It has been accepted for inclusion in Journal of Modern Applied Statistical Methods by an authorized editor of DigitalCommons@WayneState. 


\section{One is Not Enough: The Need for Multiple Respondents in Survey Research of Organizations}

\author{
Joseph L. Balloun \\ Mercer University, \\ Atlanta, GA USA
}

\author{
Hilton Barrett \\ Elizabeth City State University, \\ Elizabeth City, NC USA
}

\author{
Art Weinstein \\ Nova Southeastern University, \\ Fort Lauderdale, FL USA
}

The need for multiple respondents per organization in organizational survey research is supported. Leadership teams' ratings of their implementations of market orientation are examined, along with learning orientation, entrepreneurial management, and organizational flexibility. Sixty diverse organizations, including not-for-profit organizations in education and healthcare as well as manufacturing and service businesses, were included. The major finding was the large rating variance within the leadership teams of each organization. The results are enlightening and have definite implications for improved design of survey research on organizations.

Key words: Respondents, survey research, organizations.

\begin{abstract}
Introduction
The archetype $21^{\text {st }}$ century organization accumulates knowledge throughout its management and teams (Fisher, 1998). Because the challenges, opportunities and problems facing today's organizations are complex (many interdependent variables), complicated (shades of gray instead of black and white) and require integration of various functions (e.g., marketing, finance, operations), it is difficult for a single leader or even a small group to manage an organization effectively. The concerted and integrated efforts of executives, managers and empowered goal-oriented teams are required for optimal performance (Özaralli, 2003). Many
\end{abstract}

Joseph L. Balloun is a Professor of Education. He has published extensively on social science research methods, statistical techniques, personnel management and developing information systems. Email him at: balloun_j1@mercer.edu. Hilton Barrett is a Professor of Business with nearly thirty years of experience as an entrepreneur and a corporate executive in a Fortune 500 firm. Email him at: hbarrett@mail.ecsu.edu. Art Weinstein is a Professor of Marketing at Nova Southeastern. Emailhim at: art@huizenga.nova.edu. well-run organizations have recognized the need for management diversity, with a myriad of different orientations within their management, for better decision-making (Roberson \& Park, 2004). Peter Drucker stated that a different executive "sees a different reality and is concerned with a different problem" and the executive team "uses conflict of opinion as a...tool to make sure all major aspects of an important matter are looked at carefully" in the course of making a decision (Drucker, 1967, p. $155)$.

By virtue of society becoming more diverse, organizations are also becoming more diverse in race, gender and ethnicity (Cox, 1991) and in education and other background variables (Pitcher \& Smith, 2001). Most often, the diversity cited is demographic and includes race, age and religion among others. Business professionals are also familiar with functional diversity which recognizes that accounting, marketing and operations managers tend to have different orientations and agendas (Hambrick \& Mason, 1984).

Psychographic diversity (personality traits and lifestyles) is also important. A good example of this is the learning, decision-making and communication styles demonstrated by the Myers-Briggs Type Indicator (MBTI) (Leonard \& Straus, 1997). Kilduff, Angelmar and Mehra (2000) demonstrate that these observable 


\section{ONE IS NOT ENOUGH}

sources of diversity are surrogates for cognitive diversity, something that is more difficult to measure. Rahe (2009) emphasized that the global platform for today's business decisionmaking makes it even more difficult due to the influences of local environments. The term interpretative ambiguity describes a leadership team whose individuals perceive reality (e.g., performance measures such as market orientation) in different ways because of their cognitive diversity. The resulting heterogeneity may be an impediment to successful marketing strategy implementation (Mengue \& Auh, 2005). A development of greater leadership diversity may lead to more innovative decision-making, but a more diverse group of managers can also impede group congruence and unification for attaining strategic objectives.

Industrial (or business to business) marketing research commonly uses a single respondent per organization, also known as a key informant, in survey research on organizations. Researchers should encourage organizations to have only the most highly qualified informants respond to organizational surveys (R. J. Vandenberg, personal communication, June 28, 2010). Researchers target a particular position (e.g., CEO, Purchasing Director) that reflects the purpose of a research study and the need for specific information. Practical constraints on executives' time also suggest that using a single key informant may reduce the organization's cost of responding to surveys.

Traditional research methods typically use a single respondent or key informant to represent the entire organization in multiorganization studies. Using multiple respondents for such research is rare. A review of the Journal of Marketing, Journal of Marketing Research and Journal of Marketing Theory and Practice in recent years found no studies involving more than ten organizations that used multiple respondents per organization.

It is hoped that an especially informed person, the key informant, would be able to judge and report fully the issues affecting an organization. However, organizations choose the key informants who respond to survey research. A researcher does not have direct control of the qualifications of the respondent. For those who have conducted research at the organizational level, there is a sense that a single respondent, whether a highly qualified key informant or not, may not be sufficiently representative of an organization. Members of an organization's top management team would be qualified informants, yet the degree of concurrence among the top management team is an empirical question.

Numerous authors in the management and marketing literature have called for using multiple, as opposed to single, respondents per organization (Dawes, 2000; Gray, Matear, Boshoff \& Matheson, 1998; Tsai, 2002). Multiple respondents per organization may allow for an average measurement of the leadership team's response, but even more importantly, insights into the team's variation on specific topics. Prior organizational survey research has not identified what effects may be masked or distorted by using only one respondent per organization. For example, how do several leaders in different functions within a single organization perceive a specific product's capabilities or an organizational issue?

The purpose of this study is to describe effects that may be discovered when multiple respondents per organization are used in survey research on organizations. More specifically, the focus is on how perceptions of selected strategic management constructs vary within and among organizations. The study shows what information may be gained by having more than one informant per organization.

\section{Methodology \\ Organizations and Participants}

This study employed a snowball sampling technique, which consisted of soliciting the members of several organizations, contacting members of personal networks and targeting particular firms to build sectors and industries. The resulting non-probabilistic, convenience sample consisted of 696 usable individual responses within sixty organizations. Of these sixty, 37 organizations were in the business sector and 23 were not-for-profits. An effort was made to represent a variety of industries: banking (11), education (13), healthcare (10), manufacturing (10), real estate (6), retail (3) and all other services (7). Eighteen 


\section{BALLOUN, BARRETT \& WEINSTEIN}

organizations employed 500 or more employees, and forty-two employed fewer than 500. For each participating organization, a request was made for twenty of their top management team members to complete and return the survey. The participating managers were volunteers from their organizations.

\section{Measurements}

The measures of interest in such survey projects often are perceptually based. This research project specifically used measures of organizational market orientation, entrepreneurial management, organizational flexibility and learning orientation. These constructs have been major research topics for over a decade. They have been variously conceptualized with other variables and organizational performance as researchers attempt to develop better prescriptive models for executives (Frank, Kessler \& Fink, 2010; Mokhtar \& Yusoff, 2009).

Market orientation (MKT), as described by Jaworski and Kohli (1993) has three components: generation of market intelligence, sharing of this knowledge throughout the firm and a marketing response mechanism. Narver and Slater's (1990) work defined MKT as having three tenets: customer orientation, competitive orientation and inter-functional coordination.

Learning orientation (LRN), as popularized by Senge (1990), denotes that not only do individuals have and use the ability to do both adaptive (incremental) and generative (paradigm shift) learning, but also to keep an open mind to different perspectives and have a commitment to learning (Baker \& Sinkula, 1999). When correctly practiced, the norm becomes collaborative learning. In their studies of company rejuvenation, Stopford and BadenFuller (1990) established that the development of a learning organization required flexibility and internal communication to achieve an effective market orientation. Slater and Narver stated that "a market orientation is inherently a learning orientation" (1995, p. 67).

Entrepreneurial management style and corporate entrepreneurship (ENT) are terms used to define an organization that acts entrepreneurially (Covin \& Miles, 1999). ENT is an organizational process that encourages and practices innovation, risk-taking and a proactive orientation toward customers, competition and opportunities (Miller \& Friesen, 1982); thus, there is a relationship between the dimensions of ENT and the marketing activities of the organization. Hence, the organization: (a) is proactive in obtaining intelligence on customers and competitors, (b) is innovative by reconfiguring its resources to formulate a strategic response, and (c) implements the response, which, because it is different, entails some degree of risk and uncertainty.

Organizational flexibility (ORG) is defined as the degree in which an organization is adaptable in administrative relations and the authority vested in situational expertise. Khandwalla (1977) used the term organic to define such attributes. The management theorist Mary Parker Follett, in the 1920s, emphasized the need to match an organic structure to what is now considered an entrepreneurial management style (Graham, 1995).

Each of these organizational characteristics (MKT, LRN, ENT and ORG) has been found to be positively related to organizational performance (Zahra \& Covin, 1995; Baker \& Sinkula, 1999; Ellinger, Ellinger, Yang \& Howton, 2002; Barrett, Balloun \& Weinstein, 2004). However, these four characteristics and their relationship with organizational performance have not been analyzed in a single model. This study incorporated these organizational characteristics in a single model. Furthermore, in studying these four critical success variables and their relationships to organizational performance, the study addressed two noteworthy gaps in the literature:

1. Incorporating a multiple response methodology to assess the varying leadership team members' perspectives of how organizations are perceived on each of these four variables and organizational performance; and

2. Broadening the research base from the forprofit manufacturing sector to also include service industries and the non-profit sector. 


\section{ONE IS NOT ENOUGH}

This broader perspective recognizes the $21^{\text {st }}$ century leadership team's diversity and the economic realities of our society.

Market orientation (MKT) was measured using the twenty-question construct developed by Kohli, Jaworski \& Kumar (1993). Learning orientation (LRN) was measured using Yim-Teo's (2002) ten-question scale. Entrepreneurial management style (ENT) was measured using Covin \& Slevin's (1989) ninequestion construct for innovativeness, proactive approach to customers and competition, and risk-taking. Organizational flexibility (ORG) was measured using a seven-question Khandwalla (1977) instrument. For consistency, a seven point Likert scale was used for all questions. The resulting construct measures were the averages of the item ratings in each scale.

Given the difficulties in obtaining correct financial information that is of similar nature and time period among respondents, as well as the outright refusal by many organizations to release such information, a subjective measure of organizational performance is often more practical and useful than apparently objective financial information when the latter is available (Naman \& Slevin, 1993; Sanberg \& Hofer, 1987), and because financial measures would not be comparable or necessarily applicable across the diverse organizations included in a study. Due to these difficulties, a qualitative-based, two-question rating instrument developed by Jaworski \& Kohli (1993) was used. This scale (PERF) assesses (a) how well the organization did this year versus last year, and (b) how well it did versus leading competitors or similar organizations (for businesses and non-profits, respectively). These two judgmental questions result in a subjective rating of financial performance.

\section{Data Screening}

\section{Results}

An average of twelve managers per organization participated. The harmonic mean was 9.38 respondents per organization, and the range was from four to 31 respondents per organization. The data were screened for normality, outliers and non-response bias.
Twenty questionnaires out of 716 received were discarded due to excessive missing responses. The possibility of non-response bias was tested by a within organization chronological quartile comparison of returned questionnaires: Armstrong \& Overton (1977) stated that late respondents (versus early respondents) are considered more similar to non-respondents. A set of ANOVA tests were conducted among quartile means on selected variables; these tests revealed no significant differences among earlier and later respondents.

Scale Reliability and Correlations among Scales All of the Cronbach (1951) alphas exceed Nunnally's (1978) minimum criterion of 0.70 for reliability and all are significantly greater than zero at beyond the 0.001 level (Feldt, Woodruff \& Salih, 1987). Table 1 contains the coefficient alpha reliabilities and the correlations among the scales within and among organizations. Based on related work (Barrett, et al., 2004) one-tailed tests for positive correlation were appropriate. The reliabilities and correlations all are significant at or well beyond the 0.05 level. This was expected as both theory and practice support the needed integration and interdependency among these constructs. These results support the use of all the scales and their constituent items in subsequent analyses.

Table 1: Pearson Correlations among Scales ${ }^{\mathrm{a}}$

\begin{tabular}{|c|c|c|c|c|c|}
\hline $\begin{array}{c}\text { Rating } \\
\text { Scale }\end{array}$ & MKT & LRN & ENT & ORG & PERF \\
\hline MKT & 0.92 & 0.78 & 0.65 & 0.47 & 0.62 \\
\hline LRN & 0.45 & 0.91 & 0.64 & 0.54 & 0.54 \\
\hline ENT & 0.47 & 0.29 & 0.90 & 0.37 & 0.46 \\
\hline ORG & 0.26 & 0.20 & 0.42 & 0.82 & 0.21 \\
\hline PERF & 0.49 & 0.33 & 0.33 & 0.30 & 0.82 \\
\hline
\end{tabular}

Note: ${ }^{\mathrm{a}}$ Correlations above the diagonal are among the scale means of organizations

Sample size for correlations of scale means was considered to be 60 . Correlations below the diagonal are within organizations. The 


\section{BALLOUN, BARRETT \& WEINSTEIN}

coefficient alpha reliabilities are shown on the diagonal. Sample sizes within organizations or on the diagonal were 696. All of the correlations and the coefficient alpha reliabilities were significant at or beyond the 0.01 level, with the exception of the correlation between PERF and ORG for the organization mean scores, which was significant at the 0.05 level. With two exceptions, the correlations among institutional means were greater than the correlations within organizations.

Partitioning Sources of Variance in Scale Items

An important first question is how scale item responses are related to differences among organizations, scales and respondents. Here the central question is on what percent of variance in item responses is attributable to respondent related effects versus organizational differences. For this purpose, the responses to the 48 items constituted the dependent variable. The independent variables for this analysis include: organizations, the five scales and respondents within organizations.

The sample of organizations is best considered a random effect in the analysis of variance (ANOVA) sense. If the study were to be repeated, an entirely new collection of similarly diversely selected organizations would be generated. Respondents (participating managers) are necessarily nested within their own organizations. The chosen rating scales are fixed in the sense that only in the results that apply to these specific rating scales are of interest. Items are nested within their respective scales. Each item within a scale provides a replication of what that scale measures for each respondent. The results reported in Table 1 support the use of scale items also as replicates across all the scales in the study. The overall analysis can be conducted using an ANOVA model including organizations, participants within those organizations, the rating scales and the scale items as replicates. Table 2 shows the means for each scale within the 60 participating organizations.

Analysis of Item Data with Multiple Respondents per Organization

The item data underlying the summary of Table 2 were analyzed by ANOVA. Table 3 displays the expected means squares, the observed mean squares and the significance test for each possible effect. The method of moments was used to estimate the variance components for each of the estimable effects. The percent of variance due to each effect in the intra-class correlation or omega squared sense also is shown in Table 3.

About $7 \%$ of the variance in item ratings is accounted for by organizational differences or the organization by scale interaction. Approximately $30 \%$ of the variance is due to differences among respondents within organizations or the respondent by scale interaction effect. The within organization variance due to respondent effects is likely underestimated because of the nature of cluster sampling of the organizations (R. J. Vandenberg, personal communication, June 28, 2010).

Analysis of Item Data with One Respondent per Organization

To illustrate what will happen when there is only one respondent per organization, the first respondent in each organization (by identification number in the file) was selected. The identification numbers were assigned by sequence of return of the surveys over the entire study. The identification numbers were assigned for convenience of coding, and do not have an a priori systematic relationship to the unknown expertise of the respondent. Data screening analyses supported the conclusion that response order was unrelated to scale means. The ANOVA with one respondent per organization was computed for these sixty respondents. The ANOVA shown in Table 4 assumed organizations as a random effect and scales as a fixed effect. Items within scales were replicates. Table 4 displays the expected means squares, the observed mean squares and the significance test for each possible effect. The method of moments was used to estimate the variance components for each of the estimable effects. The percent of variance accounted for by each effect also is shown in Table 4.

According to Table 4, 29\% of the variance in item responses is attributable to differences among organizations or organization by scale interaction. The variance due to respondents or the respondent by scale 
ONE IS NOT ENOUGH

Table 2: Mean Scale Ratings by Organizations

\begin{tabular}{|c|c|c|c|c|c|c|c|}
\hline \multirow{2}{*}{$\begin{array}{l}\text { Organization } \\
\text { Number }\end{array}$} & \multirow{2}{*}{$\begin{array}{l}\text { Number of } \\
\text { Respondents }\end{array}$} & \multicolumn{6}{|c|}{ Rating Scale } \\
\hline & & MKT & LRN & ENT & ORG & PERF & Row Mean ${ }^{\mathrm{a}}$ \\
\hline 1 & 15 & 3.37 & 3.33 & 3.25 & 3.86 & 4.83 & 3.73 \\
\hline 2 & 4 & 5.99 & 5.13 & 3.22 & 5.68 & 6.38 & 5.28 \\
\hline 3 & 10 & 4.72 & 4.47 & 3.75 & 4.46 & 4.85 & 4.45 \\
\hline 4 & 12 & 4.22 & 4.17 & 3.63 & 3.52 & 4.46 & 4.00 \\
\hline 5 & 14 & 4.48 & 4.59 & 4.45 & 4.31 & 5.75 & 4.72 \\
\hline 6 & 16 & 5.22 & 5.17 & 4.84 & 4.89 & 5.84 & 5.19 \\
\hline 7 & 6 & 4.18 & 4.63 & 4.30 & 4.60 & 4.42 & 4.42 \\
\hline 8 & 12 & 5.43 & 4.75 & 4.00 & 4.72 & 6.00 & 4.98 \\
\hline 9 & 11 & 5.20 & 4.97 & 5.15 & 4.17 & 4.82 & 4.86 \\
\hline 10 & 10 & 4.63 & 4.21 & 3.98 & 4.07 & 5.50 & 4.48 \\
\hline 11 & 17 & 5.11 & 4.75 & 4.48 & 3.70 & 5.79 & 4.76 \\
\hline 12 & 11 & 4.78 & 4.77 & 4.26 & 3.88 & 5.18 & 4.57 \\
\hline 13 & 18 & 5.46 & 5.07 & 5.56 & 4.84 & 5.47 & 5.28 \\
\hline 14 & 14 & 5.81 & 4.76 & 4.32 & 3.69 & 6.75 & 5.07 \\
\hline 15 & 31 & 4.57 & 4.24 & 3.80 & 4.32 & 4.68 & 4.32 \\
\hline 16 & 9 & 4.03 & 4.20 & 4.14 & 4.05 & 4.11 & 4.11 \\
\hline 17 & 14 & 3.66 & 3.54 & 2.77 & 3.07 & 4.75 & 3.56 \\
\hline 18 & 14 & 4.25 & 4.64 & 2.74 & 3.82 & 4.54 & 4.00 \\
\hline 19 & 5 & 4.80 & 4.76 & 4.47 & 3.42 & 6.00 & 4.69 \\
\hline 20 & 16 & 4.78 & 4.17 & 4.13 & 4.28 & 5.09 & 4.49 \\
\hline 21 & 13 & 4.60 & 4.52 & 4.22 & 4.12 & 4.31 & 4.35 \\
\hline 22 & 11 & 3.91 & 3.20 & 3.16 & 3.74 & 3.59 & 3.52 \\
\hline 23 & 9 & 4.48 & 4.63 & 3.77 & 4.30 & 4.50 & 4.34 \\
\hline 24 & 4 & 4.16 & 4.25 & 3.47 & 3.80 & 3.50 & 3.84 \\
\hline 25 & 13 & 5.37 & 4.62 & 4.43 & 4.63 & 4.73 & 4.75 \\
\hline 26 & 17 & 3.52 & 3.89 & 2.82 & 3.44 & 5.56 & 3.85 \\
\hline 27 & 21 & 4.57 & 4.23 & 3.56 & 3.90 & 4.10 & 4.07 \\
\hline 28 & 12 & 4.16 & 3.98 & 3.37 & 4.02 & 4.88 & 4.08 \\
\hline 29 & 22 & 5.23 & 4.60 & 4.65 & 2.90 & 5.55 & 4.58 \\
\hline 30 & 8 & 5.35 & 5.29 & 5.13 & 5.41 & 5.44 & 5.32 \\
\hline 31 & 14 & 3.87 & 3.77 & 3.25 & 4.01 & 3.93 & 3.77 \\
\hline 32 & 9 & 3.41 & 3.49 & 3.70 & 3.46 & 4.61 & 3.73 \\
\hline 33 & 10 & 3.78 & 4.28 & 4.13 & 3.91 & 4.00 & 4.02 \\
\hline 34 & 5 & 3.87 & 4.42 & 4.16 & 3.49 & 4.60 & 4.11 \\
\hline 35 & 4 & 5.01 & 4.78 & 5.83 & 4.08 & 6.13 & 5.16 \\
\hline 36 & 15 & 4.53 & 4.07 & 4.38 & 4.15 & 5.10 & 4.45 \\
\hline 37 & 9 & 4.97 & 4.20 & 4.74 & 3.33 & 5.67 & 4.58 \\
\hline 38 & 13 & 3.74 & 3.58 & 3.97 & 3.22 & 3.77 & 3.66 \\
\hline 39 & 12 & 3.35 & 3.62 & 3.26 & 3.81 & 4.83 & 3.77 \\
\hline 40 & 7 & 5.28 & 4.89 & 5.13 & 3.89 & 6.21 & 5.08 \\
\hline 41 & 15 & 4.87 & 4.92 & 4.10 & 4.65 & 6.17 & 4.94 \\
\hline 42 & 9 & 5.39 & 4.26 & 4.27 & 4.34 & 5.78 & 4.81 \\
\hline 43 & 15 & 4.19 & 4.34 & 3.19 & 3.82 & 4.90 & 4.09 \\
\hline 44 & 15 & 5.50 & 4.75 & 4.79 & 4.66 & 5.50 & 5.04 \\
\hline 45 & 7 & 5.04 & 4.53 & 3.35 & 3.21 & 4.71 & 4.17 \\
\hline
\end{tabular}


BALLOUN, BARRETT \& WEINSTEIN

Table 2: Mean Scale Ratings by Organizations (continued)

\begin{tabular}{|c|c|c|c|c|c|c|c|}
\hline \multirow{2}{*}{$\begin{array}{l}\text { Organization } \\
\text { Number }\end{array}$} & \multirow{2}{*}{$\begin{array}{l}\text { Number of } \\
\text { Respondents }\end{array}$} & \multicolumn{6}{|c|}{ Rating Scale } \\
\hline & & MKT & LRN & ENT & ORG & PERF & Row Mean ${ }^{\mathrm{a}}$ \\
\hline 46 & 6 & 3.19 & 3.67 & 3.04 & 3.74 & 5.25 & 3.78 \\
\hline 47 & 9 & 3.52 & 3.68 & 2.95 & 2.92 & 4.22 & 3.46 \\
\hline 48 & 15 & 4.77 & 4.17 & 3.72 & 3.97 & 4.23 & 4.17 \\
\hline 49 & 16 & 5.19 & 5.10 & 3.94 & 4.39 & 5.22 & 4.77 \\
\hline 50 & 5 & 5.29 & 4.82 & 4.27 & 3.71 & 5.80 & 4.78 \\
\hline 51 & 4 & 4.40 & 4.22 & 4.17 & 5.18 & 4.50 & 4.50 \\
\hline 52 & 18 & 4.57 & 4.48 & 4.73 & 3.98 & 5.11 & 4.57 \\
\hline 53 & 13 & 5.13 & 4.8 & 4.21 & 4.22 & 5.42 & 4.76 \\
\hline 54 & 9 & 5.29 & 4.57 & 4.62 & 4.35 & 5.06 & 4.77 \\
\hline 55 & 6 & 4.09 & 4.53 & 4.46 & 3.90 & 4.92 & 4.38 \\
\hline 56 & 5 & 4.62 & 4.28 & 3.42 & 4.34 & 4.30 & 4.19 \\
\hline 57 & 10 & 5.02 & 3.97 & 4.07 & 3.27 & 5.90 & 4.45 \\
\hline 58 & 8 & 4.34 & 4.33 & 3.86 & 3.89 & 5.44 & 4.37 \\
\hline 59 & 13 & 4.99 & 4.86 & 5.03 & 4.51 & 5.73 & 5.02 \\
\hline 60 & 11 & 4.62 & 5.31 & 4.12 & 4.13 & 5.18 & 4.67 \\
\hline $\begin{array}{l}\text { Column } \\
\text { Means }^{\text {a }}\end{array}$ & 11.6 & 4.60 & 4.40 & 4.04 & 4.04 & 5.06 & 4.43 \\
\hline
\end{tabular}

Note: ${ }^{\mathrm{a}}$ Unweighted means

Table 3: ANOVA with Multiple Respondents per Organization

\begin{tabular}{|c|c|c|c|c|c|}
\hline Source & $d f^{a}$ & $\mathrm{EMS}^{\mathrm{b}}$ & $\mathrm{OMS}^{\mathrm{c}}$ & $\mathrm{F}^{\mathrm{d}}$ & $\begin{array}{c}\text { Variance } \\
\text { Percentage }\end{array}$ \\
\hline Organization (A) & 59 & $\mathrm{~S}+\mathrm{cdsB}+\mathrm{bcdsA}$ & 74.42 & $3.37^{* * *}$ & 3.65 \\
\hline Respondent (B(A)) & 635 & $\mathrm{~S}+\mathrm{cdsB}$ & 22.09 & $14.36^{* * *}$ & 16.63 \\
\hline Scale $(\mathrm{C})$ & 4 & $\mathrm{~S}+\mathrm{dsBC}+\mathrm{bdsAC}+\mathrm{abdsC}$ & 520.28 & $35.14^{* * *}$ & 2.94 \\
\hline $\mathrm{AC}$ & 236 & $\mathrm{~S}+\mathrm{dsBC}+\mathrm{bdsAC}$ & 14.81 & $3.02^{* * *}$ & 3.45 \\
\hline $\mathrm{BC}(\mathrm{A})$ & 2540 & $\mathrm{~S}+\mathrm{dsBC}$ & 4.91 & $3.19^{* * *}$ & 13.62 \\
\hline $\mathrm{S}$ & 29751 & $\mathrm{~S}$ & 1.54 & & 59.72 \\
\hline Total (Adjusted) & 33225 & & 2.63 & & \\
\hline
\end{tabular}

${ }^{* * *} \mathrm{p}<0.001$; Notes: ${ }^{\mathrm{a}}$ Degrees of freedom for the effect; ${ }^{b}$ Expected mean squares; ${ }^{\mathrm{c}}$ Observed mean squares; ${ }^{\mathrm{d}} \mathrm{F}$ ratio; ${ }^{\mathrm{e}}$ Percent of variance accounted for by each effect by the sample moment method 
ONE IS NOT ENOUGH

Table 4: Example ANOVA with One Respondent per Organization

\begin{tabular}{|c|c|c|c|c|c|}
\hline Source & $\mathrm{df}^{\mathrm{a}}$ & $\mathrm{EMS}^{\mathrm{b}}$ & $\mathrm{OMS}^{\mathrm{c}}$ & $F^{d}$ & $\begin{array}{c}\text { Variance } \\
\text { Percentage }\end{array}$ \\
\hline Organization (A) & 59 & $\mathrm{~S}+\mathrm{bsA}$ & 12.80 & $8.17^{* * *}$ & 10.28 \\
\hline Scale (B) & 4 & $\mathrm{~S}+\mathrm{sAB}+\mathrm{asB}$ & 37.73 & $6.73^{* * *}$ & 2.45 \\
\hline $\mathrm{AB}$ & 236 & $\mathrm{~S}+\mathrm{sAB}$ & 5.61 & $3.58^{* * *}$ & 18.49 \\
\hline $\mathrm{S}(\mathrm{AB})$ & 2580 & $\mathrm{~S}$ & 1.57 & & 68.78 \\
\hline Total (Adjusted) & 2879 & & 2.37 & & \\
\hline
\end{tabular}

interaction is not estimable when there is one respondent per organization. By definition, with only one respondent per organization, there is no way to separate respondent effects from organization effects.

Analysis of Item Data by the Mean of Respondents within Organizations

In lieu of other evidence, it would be expected that the average of a management team's judgments would be more accurate than those of a single respondent. That is, it is important to strive to simulate the judgments of a fully qualified or key informant. Therefore, the ANOVA with the average of the item responses within each organization was repeated. The ANOVA shown in Table 5 again assumed organizations as a random effect and scales as a fixed effect, and items within scales were replicates. Table 5 displays the expected means squares, the observed mean squares, the significance test and the percent of variance accounted for by each effect.

According to Table 5, 11\% of the variance in item responses is attributable to differences among organizations or organization by scale interaction. Again, by definition, with only one respondent per organization, respondent effects cannot be separated from organization effects.
Partitioning Sources of Variance in Perceived Organizational Performance

An applied researcher should be concerned about how much difference the research design would make in modeling a dependent variable. That is, will using a single respondent or multiple respondents make a difference in the percent of variance attributed to different effects? For this purpose, the performance rating (PERF) scale was the dependent variable. The independent variables for this analysis included industry groups, organization size, organizations within industry group and size classifications and respondents within organizations.

Seven categories of industries were included in this study. A concerted effort was made to have a variety of business and nonprofit sectors represented: banking (11), education (13), healthcare (10), manufacturing (10), real estate (6), retail (3) and all other services (7). Regarding the sizes of firms included in the study: 18 employed 500 or more employees and 42 employed less than 500. Almost all of the participating organizations were from five southeastern states: North Carolina, Tennessee, South Carolina, Georgia and Florida.

Table 6 shows the results when the ANOVA includes industry, size, organization and respondent effects. By this analysis method, the statistically significant effects are differences among organizations within industry by size subgroups and respondent differences within 


\section{BALLOUN, BARRETT \& WEINSTEIN}

organizations. The observed mean squares were decomposed according to their expected mean squares. After such decomposition, organization differences within subgroups, respondent differences within organizations, and unreliability of the dependent variable accounted respectively for about $3.5 \%, 59 \%$ and $37 \%$ of the total variance. The industry, size and industry by size effects accounted for no or very small components of total variance in the intraclass correlation or omega squared sense.

The same data were re-analyzed while ignoring the possible effects of organizations, respondents and unreliability of the dependent variable because this is the more common analysis method used in practice (results are shown in Table 7). The industry and industry by size effects are now statistically significant. By this analysis, the industry and industry by size effects are statistically significant, and they account for about 3\% of the variance each, however, about $93 \%$ of the variance is attributable to the residual variance. Using the common analysis shown in Table 7 , a researcher would not discover the most important sources of variance in this study; namely the organization differences, respondent differences within organizations, and variance due to unreliability of the dependent variable.

Table 5: Example ANOVA with Organization Mean Responses

\begin{tabular}{|c|c|c|c|c|c|}
\hline Source & $\mathrm{df}^{\mathrm{a}}$ & $\mathrm{EMS}^{\mathrm{b}}$ & $\mathrm{OMS}^{\mathrm{c}}$ & $\mathrm{F}^{\mathrm{d}}$ & $\begin{array}{c}\text { Variance } \\
\text { Percentage }^{\mathrm{e}}\end{array}$ \\
\hline Organization (A) & 59 & $\mathrm{~S}+\mathrm{bsA}$ & 6.66 & $18.05^{* * *}$ & 5.99 \\
\hline Scale (B) & 4 & $\mathrm{~S}+\mathrm{sAB}+\mathrm{asB}$ & 55.71 & $38.11^{* * *}$ & 4.30 \\
\hline $\mathrm{AB}$ & 236 & $\mathrm{~S}+\mathrm{sAB}$ & 1.46 & $3.96^{* * *}$ & 5.19 \\
\hline $\mathrm{S}(\mathrm{AB})$ & 2580 & $\mathrm{~S}$ & .37 & & 84.52 \\
\hline Total (Adjusted) & 2879 & & 2.37 & \multicolumn{2}{|}{} \\
\cline { 5 - 6 } & & &
\end{tabular}

$\mathrm{p}<0.001$; Notes: ${ }^{\mathrm{a} D e g r e e s}$ of freedom for the effect; ${ }^{\mathrm{b}}$ Expected mean squares; ${ }^{\mathrm{c}}$ Observed mean squares; ${ }^{\mathrm{d}} \mathrm{F}$ ratio; ${ }^{\mathrm{e}}$ Percent of variance accounted for by each effect by the sample moment method

Table 6: ANOVA with Organizations and Respondents Hierarchically Nested

\begin{tabular}{|c|c|c|c|c|c|}
\hline Source & $\mathrm{df}^{\mathrm{a}}$ & $\mathrm{EMS}^{\mathrm{b}}$ & $\mathrm{OMS}^{\mathrm{c}}$ & $F^{d}$ & $\begin{array}{c}\text { Variance } \\
\text { Percentage }\end{array}$ \\
\hline Industry & 6 & $\mathrm{~S}+\mathrm{sD}+\mathrm{dsC}+\mathrm{bcds} \mathrm{A}$ & 13.87 & 1.24 & 0.00 \\
\hline Size & 1 & $\mathrm{~S}+\mathrm{sD}+\mathrm{dsC}+\mathrm{acdsB}$ & 0.00 & 0.00 & 0.00 \\
\hline Industry by Size & 6 & $\mathrm{~S}+\mathrm{sD}+\mathrm{dsC}+\mathrm{cds} \mathrm{AB}$ & 5.64 & 0.51 & 0.00 \\
\hline $\begin{array}{l}\text { Organizations within } \\
\text { Industry by Size }\end{array}$ & 46 & $\mathrm{~S}+\mathrm{sD}+\mathrm{dsC}$ & 11.15 & $4.99^{* * *}$ & 3.50 \\
\hline $\begin{array}{l}\text { Respondents within } \\
\text { Organizations }\end{array}$ & 636 & $\mathrm{~S}+\mathrm{sD}$ & 2.24 & $4.23^{* * *}$ & 59.44 \\
\hline Residual & 687 & S & 0.53 & & 37.06 \\
\hline
\end{tabular}

$\mathrm{p}<0.001$; Notes: ${ }^{\mathrm{a}}$ Degrees of freedom for the effect; ${ }^{b}$ Expected mean squares; ${ }^{\mathrm{c}}$ Observed mean squares; ${ }^{\mathrm{d}} \mathrm{F}$ ratio; ${ }^{\mathrm{e}} \mathrm{Percent}$ of variance accounted for by each effect by the sample moment method 
ONE IS NOT ENOUGH

Table 7: ANOVA with Organization Mean Responses Only

\begin{tabular}{|c|c|c|c|c|c|}
\hline Source & $\mathrm{df}^{\mathrm{a}}$ & $\mathrm{EMS}^{\mathrm{b}}$ & $\mathrm{OMS}^{\mathrm{c}}$ & $\mathrm{F}^{\mathrm{d}}$ & \begin{tabular}{c} 
Variance $_{\text {Percentage }^{\mathrm{e}}}$ \\
\hline Industry
\end{tabular} \\
\hline Size & 1 & $\mathrm{~S}+\mathrm{bsA}$ & 13.87 & $8.26^{* * *}$ & 3.43 \\
\hline Industry by Size & 6 & $\mathrm{~S}+\mathrm{asB}$ & 0.00 & 0.00 & 0.00 \\
\hline Residual & 1369 & $\mathrm{~S}+\mathrm{sAB}$ & 5.64 & $3.36^{* *}$ & 3.18 \\
\hline
\end{tabular}

${ }^{* *} \mathrm{p}<0.01 ;{ }^{* * *} \mathrm{p}<0.001 ;$ Notes: ${ }^{\mathrm{a} D}$ Degrees of freedom for the effect; ${ }^{\mathrm{b}}$ Expected mean squares; ${ }^{\mathrm{c}}$ Observed mean squares; ${ }^{\mathrm{d}} \mathrm{F}$ ratio; ${ }^{\mathrm{e}}$ Percent of variance accounted for by each effect by the sample moment method

\section{Conclusion}

\section{Item Mean Differences}

When multiple respondents are included in research on organizations the differences among them can be detected and evaluated for their magnitude. The effects on item means due to the respondents or due to their interactions with the rating scales accounted for several times as much variance as effects associated with organizational differences or the interaction of organizations and scales. By contrast, when only one respondent was used per organization, it appeared that $28 \%$ of the variance was due to effects related to organizational differences or the interaction between scales and organizations. However, the apparent organizational differences and organization by scale differences estimated in Table 4 are confounded with respondent-related effects.

\section{Perceived Performance Effects}

Analogous results were obtained when ratings of organizational performance were modeled from industry classification and organization size. Again quite large effects are due to differences among respondents within organizations. Ignoring such possible individual differences among respondents makes little sense. These results support the conclusion that using only one respondent per organization in survey studies on organizational differences often will not detect nor appropriately estimate the size of effects of interest. It is time to move beyond survey studies using only one respondent per organization.
Limitations

Only a small set of rating scales was used in this study, thus it is not certain that similar effects would emerge in other specific applications. However, as demonstrated, the variance among the multiple respondents' scale ratings within the organizations in this study was greater than the variance among the organizations' scale ratings for all five rating scales. In addition, the most important sources of variation in the dependent variable cannot be detected, and were not detected by one of the most common analytical methods used in such studies.

Estimating the magnitude of variance due to various effects in ANOVA often is ambiguous. Here a decomposition method was used that assumed a fully balanced design; yet that is not true in these data, and is it not likely to ever be true in real world surveys on organizations. As noted earlier, methods employed in this study probably understated the variance due to respondents within organizations. That likely downward bias in estimates of the within-organization variance reemphasizes the point that individual differences within top management teams should be overtly assessed.

Individual Differences among Top Executives Organizational leaders and scholars should be concerned because almost all of the practical and academic research utilizes a single respondent, a key informant, in survey research involving many organizations. This variation 


\section{BALLOUN, BARRETT \& WEINSTEIN}

among the respondents seems less an indicator of different perspectives on the right way to solve a problem and more the question of a common recognition of reality. As has often been asked: Is everyone reading from the same page or even from the same book? The fable of six blind men describing the elephant also comes to mind. There are also anecdotal examples of senior corporate management who share neither the strategic plan (it's confidential) nor the ongoing operating results with their team members (the world is on a need-to-know basis). There are many organizations that do not have a proper information system in place to provide their managers the information needed for innovative decision-making. Regardless, the present method of using a single respondent in organizational research carries a large risk of providing misleading findings for decisionmakers and researchers.

The diversity within leadership teams should be used to leverage individuals' perspectives to better understand what problems and opportunities exist and the possibilities to solve the former and make the most of the latter. Organizations need to leverage these same perspectives as a competitive advantage to conceptualize possible strategic alternatives and possible implementation tactics. While management may disagree on the proper objective and strategy, the leadership team should have some consistency and consensus as to the reality of actions taken and the results.

One immediate implication is that information is not being shared; this new reality in survey research data collection methodologies and in management practices needs to be recognized and corrected. The result will be better research studies and enhanced organizational decisions.

\section{Recommendations}

First, as researchers of organizations, multiple respondents must be incorporated into survey methodology. This will increase the difficulties and costs of obtaining participating organizations and it also begs the question of how many respondents within an organization. More may be better, but there is a trade-off between difficulties/costs of obtaining participants and feasible results of research projects. Based on this study, requesting multiple respondents within each organization is a reasonable request. The appropriate number of respondents per organizations cannot be estimated with confidence over all possible applications, but at a minimum, the number of respondents requested should be sufficient to ensure detection of individual differences within executive teams and to detect salient differences among organizations.

Second, it must be recognized that our own organizations, business or non-profit, can display the same vulnerabilities as those surveyed. As previously mentioned, the $21^{\text {st }}$ century organization needs to share the strategic analysis and plan within the leadership team. The organization requires an information system that provides team members access to pertinent information needed in understanding the realities of the internal and external environments. There is also a need to recognize that information is unique among the factors of production: It gains value through additional perspectives as it is shared for a common good or purpose.

No longer will the traditional business measures (revenues, profits, and market share) suffice. The challenge is selecting the right metrics to accurately capture business performance. Intuit, the manufacturer of Turbo Tax software, Enterprise Rent-a-Car, and GE now focus on a single item to gauge satisfaction based on customer's likelihood to recommend the product (Darlin, 2005). More typically, leading organizations now use marketing dashboards to understand their critical evaluative points (Clark, Abela \& Ambler, 2006). A dashboard of the most vital metrics aids executives in managing their businesses. Farris, Bendle, Pfeifer \& Reibstein stated "...no one metric is going to give a full picture. It is only when you can use multiple viewpoints that you are likely to obtain anything approaching a full picture" (2006, p. 334).

Zeithaml, et al. (2006), explain that even when batteries of items are used, the dashboard approach may yield inaccurate results because it largely reports past (rearview mirrors) or present (dashboard) data. They propose the need to develop headlight or forward-looking customer metrics such as customer lifetime value and customer equity to increase customer value. 


\section{ONE IS NOT ENOUGH}

Rearview mirrors, dashboards, and headlights may be viewed as the latest version of management information systems. Proper design, buy-in, use, and updating information systems allow the leadership team to have a shared reality. We believe that multiple respondent research can remedy some of the barriers to understanding marketing performance and answer the basic question once popularized by Ed Koch, former mayor of New York City "...how are we doing?"

\section{Further Research}

Additional research should go much further with the question of variation among respondents within an organization. Business and academic researchers need to be aware of this phenomenon. Expanded research using multiple respondents is required, but there is also a need to take the process several steps further. For example, future research using multiple respondents within an organization might segment the respondents by organizational variables such as function (e.g., marketing, finance), level (e.g., manager, director, vicepresident), and years with the organization. In addition, research could also include demographic variables (e.g., race, gender, age) and psychographic variables (e.g., individualism vs. collectivism).

The sample size of organizations needs to be larger for in-depth statistical analyses to better seek and understand the nature of the respondent effects. The combinations of respondent and organizational variables are complex. The needed research to resolve these questions will be challenging. Hopefully, this innovative research on multiple respondents will aid in better understanding the subtle causes of business variation and inspire other researchers to pursue this stream of study. Hence, the performance objective is to accurately gauge the collective wisdom of management teams rather than relying solely on a single informed (or potentially uninformed) individual per organization.

\section{References}

Armstrong, J. S., \& Overton, T. S. (1977). Estimating non-response bias in mail surveys. Journal of Marketing Research, 14, 396-401.

Baker, W. E., \& Sinkula, J. M. (1999). The synergistic effect of market orientation and learning orientation on organizational performance. Journal of the Academy of Marketing Science, 27(4), 411-427.

Barrett, H., Balloun, J. L., \& Weinstein, A. (2004). Success factors for $21^{\text {st }}$ century organizations: A multi-sector, multiple respondents approach. International Journal of Business Disciplines, 15(2), 79-88.

Clark, B. H., Abela, A. V., \& Ambler, T. (2006). Behind the wheel. Marketing Management, 30, 19-23.

Covin, J. G., \& Miles, M. P. (1999). Corporate entrepreneurship and the pursuit of competitive advantage. Entrepreneurship Theory and Practice, 23(3), 47-63.

Covin, J. G., \& Slevin, D. P. (1989). Strategic management of small firms in hostile and benign environments. Strategic Management Journal, 10, 75-87.

Cox, T. (1991). The multicultural organization. Academy of Management Executive, $5(2), 34-47$.

Cronbach, L. J. (1951). Coefficient alpha and the internal structure of tests. Psychometrika, 16, 297-334.

Darlin, D. (2005). The only question that matters. Business 2.0, September, 50-52.

Dawes, J. (2000). Market orientation and company profitability: Further evidence incorporating longitudinal data. Australian Journal of Management, 25(2), 173-199.

Drucker, P. F. (1967). The effective executive. New York: Harper Colophon.

Ellinger, A. D, Ellinger, A. E., Yang, B., \& Howton, S. W. (2002). The relationship between the learning organization concept and firms' financial performance: An empirical assessment. Human Resource Development Quarterly, 13(1), 3-21.

Farris, P. W., Bendle, N. T., Pfeifer, P.E., \& Reibstein, D. J. (2006). Marketing metrics: 50+ metrics every executive should master. Upper Saddle River, NJ: Wharton School Publishing.

Feldt, L. S., Woodruff, D. J., \& Salih, F. A. (1987). Statistical inference for coefficient alpha. Applied Psychological Measurement, 11, 93-103.

Frank, H., Kessler, A., \& Fink, M. (2010). Entrepreneurial orientation and business performance - a replication study. Schmalenbach Business Review, 62, 175-198. 


\section{BALLOUN, BARRETT \& WEINSTEIN}

Graham, P. (1995). Mary Parker FollettProphet of Management. Boston: Harvard Business School Press.

Gray, B., Matear, S., Boshoff, C., \& Matheson, P. (1998). Developing a better measure of market orientation. European Journal of Marketing, 32(9/10), 884-903.

Hambrick, D. C., \& Mason, P. A. (1984). Upper echelons: The organization as a reflection of its top managers. Academy of Management Review, 9, 193-206.

Jaworski, B. J., \& Kohli, A. K. (1993). Market orientation: Antecedents and consequences. Journal of Marketing, 57, 53-70.

Khandwalla, P. N. (1977). The design of organizations. New York: Harcourt Brace Jovanovich.

Kilduff, M., Angelmar, R., \& Mehra, A. (2000). Top management - team diversity \& firm performance: Examining the role of cognitions. Organization Science, 11(1), 21-34.

Kohli, A. K., Jaworski, B. J., \& Kumar, A. (1993). MARKOR: A measure of market orientation. Journal of Marketing Research, 30, 467-477.

Leonard, D., \& Straus, S. (1997). Putting your company's whole brain to work. Harvard Business Review, 75(4), 111-121.

Mengue, B., \& Auh, S. (2005). A test of strategic orientation formation versus strategic orientation implementation: The influence of TMT functional diversity and inter-functional coordination. Journal of Marketing Theory and Practice, 13(2), 419

Miller, D., \& Friesen, P. H. (1982). Innovation in conservative and entrepreneurial firms: Two models of strategic momentum. Strategic Management Journal, 3, 1-25.

Mokhtar, S. S. M., \& Yusoff, R. Z. (2009). Exploring the relationship of key strategic orientations towards sustainable organizational performance. International Journal of Business and Management Science, 2(1), 79-87.

Naman, J. L., \& Slevin, D. P. (1993). Entrepreneurship and the concept of fit: A model and empirical tests. Strategic Management Journal, 14, 137-153.

Narver, J. C., \& Slater, S.F. (1990). The effect of a market orientation on business profitability. Journal of Marketing, 54(4), 20-35.

Nunnally, J. C. (1978). Psychometric theory. New York: McGraw-Hill.

Özaralli, N. (2003). Effects of transformational leadership on empowerment and team effectiveness. Leadership \& Organization Development Journal, 24(5/6), 335-344.
Pitcher, P., \& Smith, A. D. (2001). Top leadership team heterogeneity: Personality, power, and proxies. Organization Science, 12(1), 1-18.

Rahe, M. (2009). Subjectivity and cognition in knowledge management. Journal of Knowledge Management, 13(3), 102-117.

Roberson, Q. M., \& Park, H. J. (2004). Diversity reputation and leadership diversity as sources of competitive advantage for organizations. Academy of Management Proceedings, F1.

Sanberg, W. R., \& Hofer, C. W. (1987). Improving new venture performance: The role of strategy, industry structure, and the entrepreneur. Journal of Business Venturing, 2, 5-28.

Senge, P. (1990). The fifth discipline. New York: Doubleday.

Slater, S. F., \& Narver, J. C. (1995). Market orientation and the learning organization. Journal of Marketing, 59, 63-74.

Stopford, J. M., \& Baden-Fuller, C. W. F. (1994). Creating corporate entrepreneurship. Strategic Management Journal, 15, 521-536.

Tsai, W. (2002). Social structure of 'coopetition' within a multiunit organization: Coordination, competition, and intra-organizational knowledge sharing. Organization Science, 13(2), 179-190.

Yim-Teo, T. H. (2002). Learning organization, a cultural breakthrough in the public sector. The Journal of Applied Management \& Entrepreneurship, 7(3), 48-71.

Zahra, S. A., \& Covin, J. G. (1995). Contextual influences on the corporate entrepreneurship-performance relationship: A longitudinal analysis. Journal of Business Venturing, 10, 43-58.

Zeithaml, V. A., Bolton, R. N., Deighton, J., Keiningham, T. L., Lemon, K. L., \& Petersen, J. A. (2006). Forward-looking focus: Can firms have adaptive foresight? Journal of Service Research, 9(2), 168-183. 